\title{
Sexual abuse: A practical theological study, with an emphasis on learning from transdisciplinary research
}

\begin{tabular}{|c|c|}
\hline \multicolumn{2}{|c|}{$\begin{array}{l}\text { Authors: } \\
\text { Heidi Human }{ }^{1} \\
\text { Julian C. Müller }{ }^{1}\end{array}$} \\
\hline \multicolumn{2}{|c|}{$\begin{array}{l}\text { Affiliations: } \\
{ }^{1} \text { Department of Practical } \\
\text { Theology, Faculty of } \\
\text { Theology, University of } \\
\text { Pretoria, South Africa }\end{array}$} \\
\hline \multicolumn{2}{|c|}{$\begin{array}{l}\text { Note: } \\
\text { This article is a reworked } \\
\text { version of a section of the } \\
\text { author's PhD dissertation, } \\
\text { 'A narrative practical } \\
\text { theological perspective on } \\
\text { the spirituality of female } \\
\text { adult survivors of childhood } \\
\text { sexual abuse', with Prof Dr } \\
\text { Julian Müller as supervisor. }\end{array}$} \\
\hline \multicolumn{2}{|c|}{$\begin{array}{l}\text { Correspondence to: } \\
\text { Heidi Human }\end{array}$} \\
\hline \multicolumn{2}{|c|}{$\begin{array}{l}\text { Email: } \\
\text { human.heidi@gmail.com }\end{array}$} \\
\hline \multicolumn{2}{|c|}{$\begin{array}{l}\text { Postal address: } \\
\text { Portion 32, Rainhill Farm, } \\
\text { Donkerhoek, Rustenburg } \\
\text { 0299, South Africa }\end{array}$} \\
\hline \multicolumn{2}{|c|}{$\begin{array}{l}\text { Received: } 06 \text { May } 2015 \\
\text { Accepted: } 07 \text { July } 2015 \\
\text { Published: } 25 \text { Sept. } 2015\end{array}$} \\
\hline \multicolumn{2}{|c|}{$\begin{array}{l}\text { How to cite this article: } \\
\text { Human, H. \& Müller, J.C., } \\
\text { 2015, 'Sexual abuse: A } \\
\text { practical theological study, } \\
\text { with an emphasis on learning } \\
\text { from transdisciplinary } \\
\text { research', HTS Teologiese } \\
\text { Studies/Theological Studies } \\
71(3), \text { Art. \#3025, } 10 \text { pages. } \\
\text { http://dx.doi.org/10.4102/ } \\
\text { hts.v71i3.3025 }\end{array}$} \\
\hline \multicolumn{2}{|c|}{$\begin{array}{l}\text { Copyright: } \\
\text { (C) 2015. The Authors. } \\
\text { Licensee: AOSIS } \\
\text { OpenJournals. This work is } \\
\text { licensed under the Creative } \\
\text { Commons Attribution } \\
\text { License. }\end{array}$} \\
\hline \multicolumn{2}{|l|}{ Read online: } \\
\hline 口ipict & $\begin{array}{l}\text { Scan this QR } \\
\text { code with your } \\
\text { smart phone or } \\
\text { mobile device } \\
\text { to read online. }\end{array}$ \\
\hline
\end{tabular}

This article illustrates the practical usefulness of transdisciplinary work for practical theology by showing how input from an occupational therapist informed my understanding and interpretation of the story of Hannetjie, who had been sexually abused as a child. This forms part of a narrative practical theological research project into the spirituality of female adult survivors of childhood sexual abuse. Transdisciplinary work is useful to practical theologians, as it opens possibilities for learning about matters pastors have to face, but may not have knowledge about. A short retelling of Hannetjie's story is given to provide information about the context of the research. Next, the transdisciplinary process that was followed is mentioned, and the questions that the transdisciplinary team had to respond to are discussed. Following that, I focus more specifically on the occupational therapist's answers, and the knowledge gained from her contribution, as an example of how a co-researcher from a divergent discipline can inform a theological study. In this case, knowledge was shared about sensory integration and how the brain processes traumatic stimuli, such as sexual abuse. Lastly, the interrelationship between Hannetjie's body stories, mind stories and spirit stories is discussed to show how the learning received from occupational therapy affected my thinking about Hannetjie's stories and the relationships between them. Thus, it is concluded that transdisciplinary work has great value for practical theology, especially in the pastor's daily work with people who are struggling with difficult stories, because we cannot listen to people's spirit stories in isolation. They are inextricably intertwined with all our stories about ourselves.

\section{Introduction}

This article serves to illustrate the value of collaboration between practical theologians and professionals from other disciplines. Input from a professional in another discipline is used as an example of how possibilities can open up within practical theological research if a transdisciplinary approach is employed.

Narrative research was conducted regarding the spirituality of female adult survivors of childhood sexual abuse, in a postfoundational, social constructionist framework. The original research consisted of a layered, single case study, with the transdisciplinary study functioning as the third layer, used to thicken the original story and open up possibilities for meaning outside of the context of that single story (see Box 1). The aim was to gain insight from outside perspectives and find a 'wide reflective equilibrium' (Van Huyssteen 2006) - a place where different knowledges can overlap and converge to generate new insight. This layer of the research served to inform the researcher's choices about literature and further interpretation of the original story. In this article, one specific participant's contribution will be highlighted to show what value transdisciplinary work could have for narrative, practical theological practitioners.

\section{Why can transdisciplinary work help?}

Practical theology is theology of real, everyday life. As Müller (2013:1) points out: 'Practical theology is known for its fluidity and dynamics which enables it to move eloquently between various fields of study.' Sometimes, people need a friend to help them with something mundane, and sometimes people need someone to help them face their nightmares. When it is time to help someone face their nightmares, the task is 'costly and dangerous' (Campbell 1986:36). Moreover:

\footnotetext{
... all persons, whether young or old, sick or healthy, rich or poor, have ongoing needs for meaning, love, relationship, and community, and pastoral care is the form ministry takes as it strives to help people meet these needs... (McClure \& Miller-McLemore 2012:269-270)
}

This is the work of the pastor. Therefore, it is also the work of the pastor to explore knowledges from a variety of different fields, as necessary, because pastors need to acknowledge that their own knowledges are limited and take a humble approach. 
BOX 1: Layered research project.

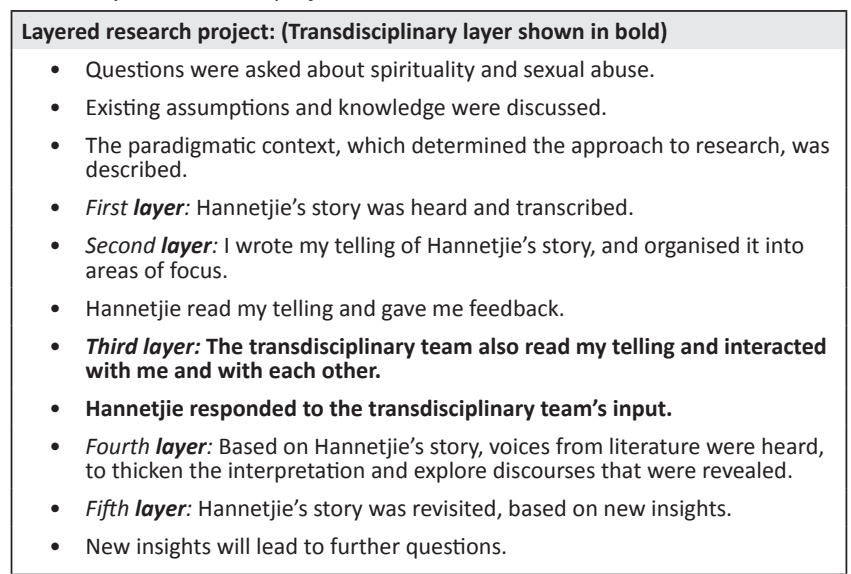

Transdisciplinary research is not a new concept, nor is it unique to practical theology, but it plays a special role within a postfoundational, social constructionist research project, such as this one. Within the postfoundational paradigm, researchers need to hear the voices of professionals from other disciplines to enrich and deepen their understanding of the story being heard, in order to seek a 'balance' between their own thinking and the broader traditions of thinking that may influence their understanding (Müller 2009:205).

It is important to mention the context of the research, because 'experience is situated and experience is always interpreted' (Müller 2009:205), which means that research based on experience is contextual. This article is based on a single case study that tells the story of Hannetjie (this is a pseudonym), who was sexually abused as a child. Hannetjie is an Afrikaans-speaking woman from the Dutch Reformed Church, who shared her story as part of research into the spirituality of female adult survivors of childhood sexual abuse. Although hers is only one story:

\footnotetext{
... a postfoundationalist notion of rationality helps us to acknowledge contextuality, the shaping role of tradition and of interpreted experience, while at the same time enabling us to reach out beyond our own groups, communities and cultures, in plausible forms of intersubjective, cross-contextual, and crossdisciplinary conversations. (Van Huyssteen 2006:ch. 1)
}

In other words, in an effort to move beyond Hannetjie's story to a point where her story can be of value to others, the decision was made to invite other professionals into the conversation.

Müller (2011:4) adds significantly to Van Huyssteen's reasoning when he makes the case for practical theology as emerging out of 'religion in the praxis of human life' and that 'practical theology leaned heavily on social sciences for the description and explanation of human behaviour within a religious context' (Müller 2011:4). Having developed in parallel with the social sciences, practical theology shares some common ground with the social sciences, while asking questions about God and faith. Müller acknowledges that there are 'natural limits to dialogue between disciplines' (Müller 2011:4) because, despite potential overlap, each discipline still functions within its own context. However, because of the close relationship between practical theology and the social sciences, he argues for what he calls the 'edge effect' (Müller 2011:4). This 'edge effect' takes place when different disciplines operate together within an even larger context. As Fuqua et al. (2004) explain:

Although disciplines are defined as distinct fields of inquiry, the boundaries around disciplines are in fact somewhat arbitrary (having fuzzy boundaries). In turn, the boundaries between closely related fields [...] are often overlapping rather than mutually exclusive. (p. 1460)

In the juncture between disciplines, there is space for rich growth and development as the resources of both can be drawn upon. Thus, transdisciplinary work can encourage growth in practical theology.

\section{Hannetjie's story}

Since Hannetjie's story forms the backbone of the research, it is important to have an overview of her story. This will provide context for the transdisciplinary study that is discussed in this article. A much abbreviated version of Hannetjie's story follows, based on some unstructured interviews and emails, including one in which she shared a collection of her poetry. The original, longer version was provided to the transdisciplinary team, but it is shortened here to serve as background to the discussion on the transdisciplinary work that follows.

Hannetjie was introduced to me as a woman in her late forties, working as an accomplished professional in the academic world. We communicated directly via email at first - during this correspondence, she was informed about the nature of the research and provided with an informed consent document that she eventually signed.

She had been sexually abused by a friend of the family for approximately eight years from the age of eight until she was 16 , stating that the last incident ended in rape. Mostly, he had fondled her and performed a number of different sexual acts with her as well as forcing her to reciprocate. These events culminated in this final act of rape. She explains that this is the only incident where he had penetrated her and this is why she refers to this specific incident as 'rape'. Shortly after that, she went to university and, by doing so, was able to escape further abuse.

She was raised in a conservative, Dutch Reformed household. She has an older brother. Her parents were never aware of the abuse and she felt unable to tell her mother for a number of reasons. She describes her upbringing as strict and authoritarian.

As a result of the abuse, she was socially awkward and withdrawn, preferring her own company and the company of books to that of other people. She found university particularly difficult to adjust to socially, but found her escape in academics. Subsequently, she entered the professional 
world (which she also finds challenging socially) and earned a number of different postgraduate qualifications. She explains that this has been a way for her to run away from facing her emotions and to fill sleepless nights. She remains single, despite having had a handful of romantic relationships, all of which ended as a result of her reluctance to make intimate connections or to respond to physical intimacy. Working as a lay counsellor has provided her with the opportunity to support others in distress and to have an outlet for her deep-seated concern for others, especially those who are vulnerable. She avoids dealing with rape cases, though, because of her history. She also volunteered at a number of other charitable organisations. Recently, she has become increasingly aware that she is averse to almost all physical contact and stimuli. She has also become convinced of the need to address this aversion, as it is affecting her ability to interact with others in even the most casual of circumstances. She has consulted a number of professionals for support over the years and, at the time of the interviews, was in therapy. Hannetjie is still haunted by nightmares and feelings of guilt and shame, more than 30 years afterwards. One of the reasons for these lasting effects is that her abuser is still a friend of the family and still lingers in the background.

Throughout the time of the abuse, and since then, Hannetjie has found ways of escaping the pain. At the time, she said:

'The only way I could survive eight years of abuse was to tell myself that I felt nothing. "I feel nothing. I feel nothing. I feel nothing. I feel nothing".'

This repetitive mantra became her shield. Subsequently, though, she has found it very difficult to reconnect with her own feelings - both on a physical and an emotional level because she became so good at cutting herself off from sensation and emotion. Later in life, she supplemented this suppression of feelings with an attempt to run away, as she describes it:

'I lived most of my life on an intellectual level. I studied and the moment I finished one degree, I would start the next one. Not to think. Not to feel. Not to live. Not to experience. Because I am a master at suppressing my own emotions.'

Also, she used her studies to escape nightmares, which came back more often 'the moment I let go a little', referring to letting go of her emotions.

She tells the story of the day she realised that her aversion to being touched was out of control:

'I was sitting in the boardroom, reading the minutes of the previous meeting. I was sitting with my back to the door and someone came in. I didn't hear her and she put her hand on my shoulder. I punched her [...] it was a reflex action. She got a big fright and so did I. It was an overreaction. I realised that I have to make a plan. [...] It was a fright, but the reaction wasn't normal. Your first reaction shouldn't be to flatten the person.'

Since coming to this realisation and noticing a pattern in the manner in which she would avoid sitting between two people at church or feel completely drained by a 15 minute visit to a medical professional, she has made every effort to acquire a better understanding of not only her own reactions to physical contact, but also her emotions and feelings. She describes this pursuit as an effort 'to be one'. Upon questioning her about what she means by this, she explains that she is currently half a person. She feels that she is only comfortable with some parts of her body and as if 'the middle part' - referring to her lower torso - is missing. She feels perfectly comfortable with her own mind and intellectual pursuits, but she feels decidedly uncomfortable with her own physical reality, almost as if she is disembodied. It is this sense of disembodiment that led me to wonder whether there may be a discipline outside of theology that could teach me more about Hannetjie's relationship with her body.

\section{Transdisciplinary process}

A brief description of the transdisciplinary process follows, followed by an explanation of the contribution of one transdisciplinary team member. Each team member was given the opportunity to read the prose version of Hannetjie's story that I had written and was asked to respond to the following four questions, adopted from Müller (2009):

- When reading Hannetjie's story, what do you think her concerns would be?

- How would you formulate your discipline's unique perspective on these concerns and why is it important that this perspective be heard at the transdisciplinary table?

- Why do you think your perspective will be understood and appreciated by co-researchers from other disciplines?

- What would you like to learn from the co-researchers from other disciplines? (p. 227)

The questions are in keeping with the aims of transdisciplinary research in general, as well as with postfoundational social constructionist ideals, in that the answers would create space for professionals to look for areas of consensus and dissensus, and for me to identify potential moments of new learning (Van Huyssteen 2006). Similarly, the fourth question was added to encourage transdisciplinary team members to think not only about what they will bring to the table, but also about what they hoped to take away, in the reciprocal spirit of transdisciplinary studies. Transdisciplinary team members were asked to answer the questions and were given the opportunity to read, and respond to, one another's answers.

Furthermore, ethically, in order to honour Hannetjie's authorship of her own story (Epston 1999), and to empower her as co-researcher, she was also invited to respond to the feedback from these professionals, giving her an opportunity to reflect on and accept or reject their readings of her story. After all, following in Foucault's footsteps, a feminist, narrative researcher questions 'the privileges of knowledge' (Foucault 1982:781) and decentres the researcher from her traditional position of power to place the co-researcher at the centre. 
In thinking about an inductive, transdisciplinary research design, postfoundationalism guides the researcher in the manner in which to place the co-researcher (in this case, Hannetjie) at the centre. Van Huyssteen (2006) explains:

On a postfoundationalist view of rationality, the narrative quality of one's experience, therefore, is always compelling. And in this sense a postfoundationalist notion of rationality is never going to function as a superimposed, modernist metanarrative, but will always develop as an emerging pattern that unifies our experience without in any way totalizing it. (ch. 1)

Therefore, the original narrative served as the point of reference for any decisions made about this transdisciplinary process and on how to interpret the data that emerges. In this case, I decided to allow Hannetjie's story to inform any choices made about the transdisciplinary study. Consequently, I decided to approach a psychologist, an occupational therapist and a Dutch Reformed minister, as each of their fields of study could helpfully inform the research.

Specifically, the choice was made to invite an occupational therapist because of her interest in and work with clients on a sensory level, using the theories of sensory integration and sensory intelligence (Ayers 2005; Bundy \& Murray 2002; Lombard 2007) as a way to begin thinking about Hannetjie's sense of disembodiment. Furthermore, the choice to focus on the occupational therapist's input for this article was made to illustrate how valuable it can be to work with a person from a field that is quite divergent from practical theology - as opposed to psychology, which is familiar territory for most theologians (Müller 2013).

In Boxes $2-6$ is the occupational therapist's biography and responses to the four questions.

\section{BOX 2: Biography: Debra Smuts, Occupational Therapist.}

I am an occupational therapist, working in the field of acute adult psychiatry. I share a partnership in a private practice at a private psychiatric hospital where we mostly do occupational group therapy. I am a registered Sensory Intelligence Practitioner and busy with final certifications as TRE (Trauma Release Exercise) Practitioner. I am also a member of the Dutch Reformed
Practical Christianity Focus Group in our congregation.

Many of my clients/patients have stories similar to Hannetjie's. I am always looking for better perspectives and believe in the advantages of teamwork. By taking part in this study, I can learn from but also bring expertise to contribute to this study. I have always believed that a holistic approach is far more effective than going it alone. On a personal level, I am concerned about the relevance of the church (the Dutch Reformed Church in particular) in everyday life, thus my involvement in the focus group.

\section{BOX 3: First question}

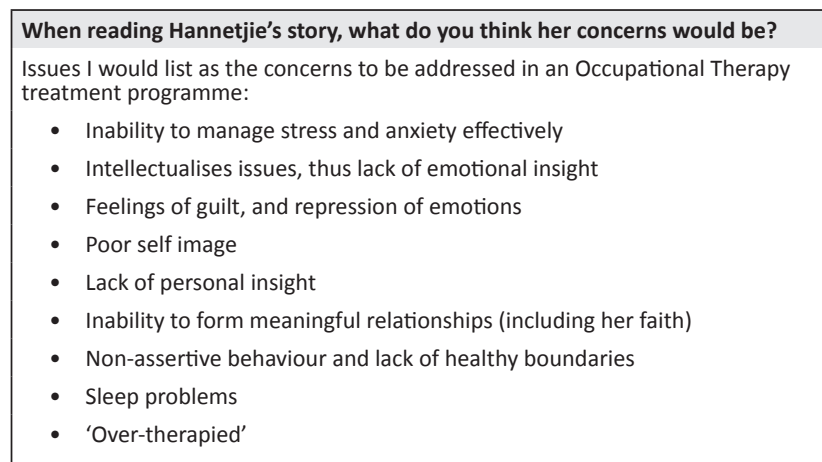

BOX 4: Second question.

How would you formulate your discipline's unique perspective on these concerns and why is it important that this perspective be heard at the transdisciplinary table?

As an Occupational Therapist, I look at these issues from a functional perspective. Thus, I take the background into consideration, but only work in the here-andnow, taking as the aim of treatment every aspect of her life that is affected, while attempting to reach optimal independence and quality of life in her work as well as personal and interpersonal roles of life. I believe in involving Hannetjie by setting realistic, graded targets for her healing process and optimising her ability to live life to the full.

Later response:

In human development we use the term 'sensory integration'. As the nervous system develops and matures, our various senses interact and integrate with each other in order to produce certain functions: the easiest and best-known example would be hand-eye coordination. In adults we no longer use the term integration; we apply sensory intelligence. Sensory intelligence is the way the senses are used to process information from and adjust to stimuli from the environment. used to process information from and adjust to stimuli from the environment. Annemarie Lombard, author of Sensory Intelligence. Why it matters more than IQ and EQ (2007), describes it quite aptly as the 'senses trying to make sense of the environment'. The theory is based on the sensory integration theory of Ayres and thus there are some common principles. Individuals have unique sensory profiles and preferences. Sensory processing and thresholds cause many of the adaptive behaviour responses in activities of everyday life. Nobody senses or experiences the world in exactly the same way. By working out a person's unique profile, the way that the individual perceives the environment and adjusts to it can be understood. Changes in the environment automatically trigger the stress response and what for one person might just evoke a slight reaction, might for the next trigger severe discomfort or even anxiety.

I would apply this theory and accompanying treatment principles regardless of whether my clients were male or female.

Sensory profiling is non-threatening. Any discussion of the implications of individual preferences and triggers and how these impact on daily life activities will reconnect individuals with themselves: a wonderfully safe approach to address dissociation. With this awareness comes the added benefit of tools to adapt the environment to be less stressful. Rather than the environment controlling the person, the individual now controls the environment (this is perhaps oversimplified, but it all concerns internal locus of control). It is also at this point where I will introduce stress reduction techniques, such as TRE (trauma release exercises), as it is another self-regulatory tool and thus also not therapist-directed. SI and TRE will give a person such as Hannetjie a sense of taking back control, and this should facilitate her in taking ownership of her wellbeing.

BOX 5: Third question.

Why do you think your perspective will be understood and appreciated by coresearchers from other disciplines?

People such as Hannetjie require the professional services of all three of us and may well present with different needs at first; very often though, the reason for the need to seek help will stem from abuse as a child. To me, people such as thannetjie might present as a patient who was hospitalised after a suicide attempt Hannetjie might present as a patient who was hospitalised after a suicide attempt
and who is now diagnosed with a psychiatric illness and/or personality disorder; to another she might be the one who goes to seek help because of her inability to form intimate relationships. We are bio-psycho-social-spiritual beings and have the need to grow and be independent in all of these. Occupational Therapy (OT) is a very practical form of therapy: it provides a functional and holistic approach to treatment. We assess an individual's ability and level of functioning in all spheres of life, taking the philosophy from occupational science that our doing defines our being. We also assess an individual's motivation to participate in all these spheres of life in order to provide the right challenge in therapy to help the client to take part in the process by giving regular feedback. When one reads Hannetjie's story, it is in the process by giving regular feedback. When one reads Hannetjie's story, it is clear that she has severe functional obstacles preventing her from having proper quality of life. She also mentions that she tends to intellectualise her problems. OT provides the opportunity to address these issues in a practical way in a safe environment. We would assess the person's function in every aspect of life (personal, interpersonal, work and leisure), formulate a treatment programme based on the client's level of motivation, providing a 'just-right-challenge' to improve insight and to promote taking ownership of a person's own wellbeing.

BOX 6: Fourth question.

What would you like to learn from the co-researchers from other disciplines?

It is always useful to get as many perspectives as possible. In order to understand a topic in full and to get better insight, it helps to learn about the approaches followed by other professions: by doing this, I can then make better recommendations for clients who need referral to one of the other professions. I love clinical reasoning and exploring new avenues. At the end, it is not about us or our profession, but about what is best for our client.

\section{Consensus and dissensus}

In the original transdisciplinary conversation (D. Smuts, A. Reynolds \& L. Viviers pers. comm., 07 August - 10 October 2014), attention was paid to moments of consensus and dissensus among the transdisciplinary team members. On the whole, there was much consensus with regard to the 
transdisciplinary team members' concerns about Hannetjie's seeming lack of relational connectedness and her struggle with feeling disembodied. There is, in fact, very little that the transdisciplinary team members did not agree on, but it is important to note a question that Debra raised. As the only participating professional who works in a clinical setting, she was concerned about the level of pathology evident in Hannetjie's story, and wondered why no one was acknowledging it.

As a narrative researcher, I am wary of a concept such as pathology because of its association with the positivistic duality of illness and health, as well as the implication that the problematic aspects of Hannetjie's story would place Hannetjie in the marginalised position of a 'sick person in need of an expert to cure her', as opposed to the narrative notion that Hannetjie has the power to re-author the problematic stories in her life to construct preferred stories in other words, that she is the expert on her own life. In addition, the concept of pathology points toward the possibility that Hannetjie's problem-saturated story is devoid of potential - something to get rid of, rather than to gain knowledge from. Stephen Madigan (2011) explains that:

... commonly accepted binary descriptors such as healthy/ unhealthy, normal/abnormal, and functional/dysfunctional ignore both the complexity of people's lived experiences as well as the personal and cultural meanings that may be ascribed to their experiences within a given context. (ch. 3)

From a narrative perspective, Hannetjie's story would be described as 'problem saturated' rather than pathological.

From this perspective, the problems that people encounter can be situated within a dialogic context and not placed under individual sovereignty. Within narrative therapy's mode of practice, problem-saturated stories in our lives are seen to gain their dominance at the expense of more preferred, alternative or subordinate stories that are often located in marginalised discourses (Madigan 2011:ch. 3).

Thus, the aim of therapy would not be to 'cure' her, but to elicit preferred stories. Hannetjie's own response to the transdisciplinary input is a case in point. She acknowledges that her decision not to disclose the truth to her mother may have been a problematic one, but she prefers not to disclose. It is a story she does not want to tell. In the literature regarding disclosure of sexual abuse, disclosure and seeking social support are seen as 'constructive coping' mechanisms (Merrill et al. 2001:1003), so it would make sense, from a psychological perspective, to encourage Hannetjie to disclose to her mother, as the psychologist who participated suggested. It was helpful, in discussing this matter further with Debra, to consider the potential for a combined clinical and narrative approach in understanding the challenges a survivor of abuse might face, having some background knowledge of the possible pathology. As she explains:

Serious trauma, like Hannetjie's, in childhood often leads to pathology. It is all about survival; the child must fight for everything she wants in life, or even just for survival; another may have to be the least in every situation to keep the peace; some only want to take revenge, etc. - all to protect the ego. Then there are also the illnesses, like post-traumatic stress disorder and obsessive-compulsive disorder. Anxiety is the motivator here, and can immobilise a person, or, simply, steal life from the person by trapping them in rigid thought patterns like, 'people are untrustworthy,' or 'relationships are dangerous,' or 'love is not for everyone.' Medication and therapy can support the healing process in such an instance. (D. Smuts pers. comm., 07 October 2014)

However, from a narrative perspective, the researcher would take a different position. 'The normative position invites the professional person to look for commonalities among people; to predict, interpret, classify, and deploy ideas that are considered tried and true' (Monk et al. 1997:24). Ethically speaking, the story belongs to Hannetjie and she is the author. If, for example, a 'rigid thought pattern' were identified by Hannetjie, then the narrative researcher would probably refer to it as a discourse or dominant story and explore it as such. The narrative researcher approaches research in a manner similar to narrative therapy, as Monk et al. (1997:25) indicate: '[T]he unchecked power or certainty of the counselor's expertise may easily silence knowledges and abilities that might otherwise have come forth from the client.' Thus, Hannetjie's telling and her choices remained central to my reading of her story. However, Debra's input broadened my perspective on Hannetjie's telling, with regard to my need to understand the manner in which the brain processes experiences, so that I could understand the impact of the abuse better.

\section{Learning from Debra}

It must be noted at this point, that I made the decision to focus on Debra's input for this article as, out of the three transdisciplinary contributors, her input serves as the clearest illustration of how practical theologians can learn from another, very different discipline, since occupational therapy is more closely associated with Health Sciences. In contrast, the other two team members' disciplines and training are closely related to the field of practical theology Mr Reynolds is a psychologist and Ds Viviers is a Dutch Reformed minister who specialised in Ancient Languages.

Having read Debra's input, I looked at Hannetjie's story afresh, concentrating specifically, in this case, on how understanding sensory integration and sensory intelligence could shed light on Hannetjie's story. The reason is that, in discussing her abuse story with her, I found that she dwelt on the long-term effects of the abuse, describing sleepless nights, nightmares, a sense of disembodiment, and an aversion to touch. All of these effects are common among survivors of abuse, as discussed by Finkelhor (1986, 1990), Heitritter and Vought (2006), Bass and Davis (2002), and Hagood (2000). As Finkelhor (1990:328) states, these effects often resemble symptoms of post-traumatic stress disorder 
and include 'nightmares, numbing of affect, a sense of estrangement, sleep problems'. Based on Debra's input, I read more about the brain and sensory integration. Emily Lyon (2010) explains these effects from a neurological perspective. She states that:

Under situations of manageable stimulation the hippocampus and cerebral cortex compare new events with past experiences, orient the person to time and space and inhibit the chemical systems of the brain from over-arousal. In this case memories are stored in 'explicit memory' which is conscious and can usually be recalled. However, in a traumatic situation, the brain is overwhelmed with the biochemicals generated by the fear response so that the normal action of the hippocampus is blocked. As a result, the inhibiting chemicals usually triggered by the hippocampus are not released into the brain, so that the activating chemicals continue to over-stimulate the limbic system. [...] and [these memories are] stored in the body where the memories retain the unprocessed emotions of terror. (pp. 236-237)

Lyon (2010:237) explains that these 'implicit memories' are the ones that are 'triggered' by seemingly harmless situations, such as Hannetjie's colleague who touched her shoulder from behind and caused her to punch her. These are also the memories that manifest as nightmares.

Steine et al. (2011:1836) found a connection between the frequency and severity of survivors' nightmares and their perceived social support, as well as to the intensity of the abuse. In Hannetjie's case, it makes sense because she has not disclosed the abuse to many people and is essentially fighting the battle on her own, except for the support she gets from therapy. As Steine et al. (2011:1837) explain: '[T]hose with lower support levels might feel overwhelmed by their problems, leading to cognitive-emotional arousal and consequently sleep problems.' She has made the decision never to disclose the abuse to her family and, ultimately, not to experience the potential healing that could come from disclosure. Palmer et al. (1999:263) tell us that 'disclosure is therapeutic for children because it changes secretiveness to openness, shame to self-satisfaction, confusion to understanding, and numbness to expression'. However, Palmer et al. (1999:273) also describe the helplessness felt by those who felt unable to disclose, or felt that they were not believed, or felt that no-one was doing anything. Hannetjie felt unprotected, because her mother was trained to know and work with victims of abuse, but did not see what was going on with her own child.

As Hannetjie testifies, these various effects have all been present since the abuse started and all work together. She may not be a natural insomniac, but in order to avoid the nightmares, she does not sleep. She wants to be connected to her body, but she has taught herself not to feel and, as Bass and Davis (2002:35) explain: 'But since you can't block feelings selectively, you simply stopped feeling.' In shielding herself from the pain of abuse, she has shielded herself from all feeling and, as will be discussed later, this has had a disastrous effect on her love life.

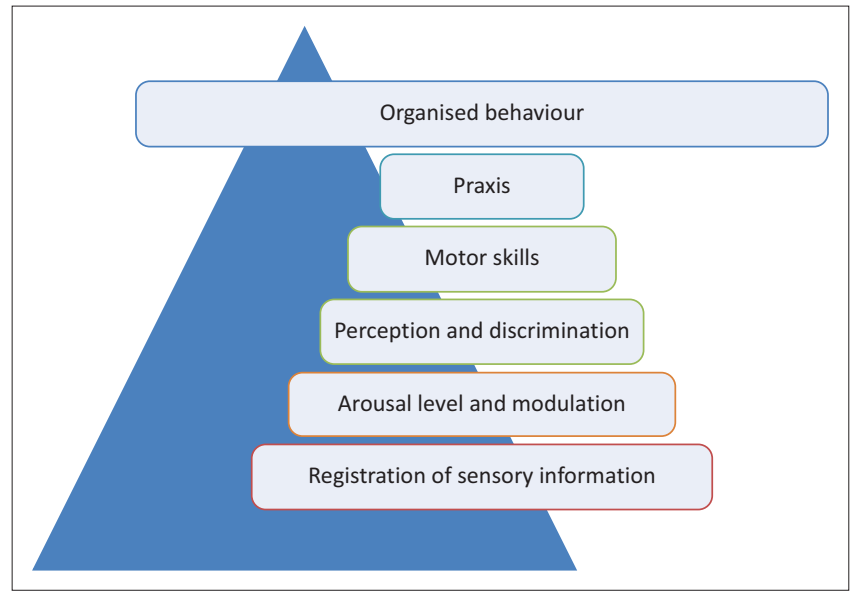

FIGURE 1: Levels of sensory integration functions.

Knowledge of how the brain is supposed to process sensory input may shed light on Hannetjie's difficulty with certain types of stimuli. Figure 1 provides an adaptation of Van Jaarsveld's (2012:18) graphic representation of the levels of sensory integration functions.

Following the logic presented in the above figure, sensory integration occurs in stages. The first stage is the sensory input itself, which is registered by the neurons in the sense organs, for example, the skin, ears, eyes and tongue. Under normal circumstances, the nervous system receives input from all the senses all the time, as Lane (2002:106) states: '[M]any neurons are receiving inputs from many sources simultaneously.' As such, the brain becomes aroused, because a decision needs to be made about whether to act on the input or not. For example, when somebody touches something very hot, the input needs to be translated by the nervous system into action - in this example, taking the hand away. However, not all stimuli are useful. For example, the constant sensation of clothing rubbing against skin needs to be filtered out or else the person will become over-aroused for no reason and find it impossible to wear clothing. The process of filtering input is known as modulation (Lane 2002:104): 'Filtering of sensations and attending to those that are relevant, maintaining an optimal level of arousal, and maintaining attention to task all require modulation.' The brain's ability to manage arousal and to modulate is the second level of functioning. Thirdly, once input has been modulated, higher cognitive functions can process the input and discriminate between sensations, and make decisions about which actions to take and how to feel about the input. Emotional and intellectual processing of sensory stimuli are only possible once arousal has been managed. After that, more complex responses can be managed as well. If the sensory input is overwhelming, as in the case of sexual abuse, for example, it is not processed well at the most basic level. Modulation becomes difficult, and therefore discrimination becomes difficult.

At this point it is appropriate to consider the confusion that survivors experience when previously overwhelming and therefore badly processed - stimulation that was 
associated with trauma is now presented as love: this scenario could typically arise in the situation of sex with a consenting partner, or even in the case of a friendly touch on the shoulder. How does a person's skin discriminate? At the highest levels, praxis (the ability to form new responses to new stimuli) and organised behaviour are impossible. Bundy and Murray (2002:5) explain: 'Individuals who have a decreased ability to process sensation also may have difficulty producing appropriate actions, which, in turn, may interfere with learning and behaviour.' Hannetjie's defence against this problem is to avoid any physical contact with other people as much as possible. In terms of sensory integration, this is referred to as sensory defensiveness (Bundy \& Murray 2002:9): 'Sensory defensiveness is a fight-or-flight reaction to sensation that others would consider non-noxious [and is] linked to poor limbic or reticular system processing.' The limbic system 'plays a role in learning and memory; eating and drinking behaviors; aggression; sexual behavior; and, importantly motivation and expression of emotion' (Lane 2002:110).

Let us briefly return to Lyon's (2010:237) discussion of traumatic memories and the limbic system. If we bear in mind the sensory integration process described here, then Lyon's explanation rings especially true: thus, the trauma is not processed well and is stored in the limbic system to return as flashbacks and nightmares. In Hannetjie's case, we can observe two types of reactions to sensory input. On the one hand, she overreacts to touch, as in the example she gave of punching her colleague, which leads to defensive, or avoidant, behaviour. On the other hand, she finds herself unable to discriminate between sensations, as in the instance when she explained to me that she was the only one in the office who did not realise that the air conditioner was not working, and she under-responds or feels nothing. Lane (2002:109) suggests that one may display behaviours that could be described as 'defensive reactions until overload [leads] to shut down in the processing of sensory input'. As such, sensory defensiveness could include a number of behaviours that appear contradictory - overreaction or shut down. The behaviours, as such, are not the problem. It is 'not so much that [clients] over- or underrespond to sensation but that their behavior reflects poor modulation and its many ramifications' (Lane 2002:109). I want to suggest that many, if not most, of Hannetjie's current challenges with physical sensations and emotions stem from the years of inappropriate and overwhelming sensory and emotional input that she endured. She failed to process and modulate adequately that which she describes as the divide between her intellect and both her emotions and sensations.

The divide that Hannetjie experiences between her intellect, emotions and sensations is artificial, which is why she feels incomplete. As Debra also commented: ' $[W]$ e are bio-psychosocial-spiritual beings.' It is not natural to try to separate the inseparable. Thus, it is important that theologians understand the interaction between our body stories and our spirit stories.

\section{Stories about Hannetjie}

Hannetjie's various stories about herself relate to one another. Here, the relationships between her body story, her mind story, and her spirit story will be discussed. These will be discussed within the context of inputs received from occupational therapy, as well as insights gained from literature regarding embodiment and the role of the brain in all three spheres. It is important to be aware that, from a holistic, embodied perspective, the conceptual divisions between body, mind and spirit are outdated (Turner 2001). Hannetjie's body stories, mind stories and spirit stories are conflicted because, in her telling, she has revealed that she feels disembodied. In other words, the division has become real for her and it feels unnatural and has subsequently caused problems for her.

Firstly, the distinction between body stories, mind stories and spirit stories within the context of this discussion needs to be explained as far as possible. Jeeves's (2014:103) concept of 'duality without dualism' may prove helpful here as he explains: 'As far as people are concerned, the primary ontological term is "person", the individual subject of whom we assert two types of predicates, mental and physical.' To this, I would like to add the spiritual predicate as a third part of this 'primary ontological term'.

In referring to Hannetjie's body stories, I am concerned with the stories that tell of her physical body and physical experiences, including sensory experiences and how the brain processes them on a biological level. Hannetjie's mind stories are those that she tells about her intellect, identity, conscious choices and thinking. The mind is a larger, more complex phenomenon than the brain, and much debate and research have been entered into regarding the relationship between the two (Maiese 2011; Scruton 2011). When her spirit stories are mentioned, then I refer to those tellings that can be connected to her relationship with God, including moral and ethical stances and her expressions of faith. Tanyi (2002) defines spirituality as follows:

Spirituality is a personal search for meaning and purpose in life, which may or may not be related to religion. It entails connection to self-chosen and or religious beliefs, values, and practices that give meaning to life, thereby inspiring and motivating individuals to achieve their optimal being. (p. 506)

The identification of those stories that relate to God, her religious life, values and beliefs, faith, hope, healing and empowerment, as Tanyi (2002) mentioned, plays an important role in this interpretation - after all, these elements all point to her spiritual story. It must be noted that these narratives will not be dealt with as individual stories, but in relationship to one another.

Hannetjie's body stories are stories of conflict, as it is through her body and her physical experiences that she was violated and abused. Her senses and brain responded to the trauma in such a way that all later physical touch became difficult to process (Wilson, Hansen \& Li 2011). As such, she distanced 
herself, feeling increasingly disembodied. On a physical level, she closed herself off from sensory experience, avoiding physical touch, as tactile defensiveness is often an effect of sexual abuse (Kinnealey, Oliver \& Wilbarger 1995:449). This has had far-reaching consequences for her in terms of life choices, in view of her conscious decisions to avoid physical touch and sensory input to minimise anxiety (Pfeiffer \& Kinnealey 2003). She has done this so well that she has become largely unaware of her senses. Instead, she has preferred to live out stories of the mind, focusing on an intellectual, academic career and pursuing solitary activities, such as reading in her private time. Furthermore, even in her attempts to understand the abuse as well as her own sexuality and spirituality, she has chosen intellectual pathways, such as studying Comparative Religion and making a survey of different religions' approaches to sexuality. She also feels betrayed by her body, because it became aroused during the instance when the abuser raped her, further reinforcing her distrust in her physical reality. The years of abuse have left her with contradictory body stories. On the one hand, she acknowledges that she has 'normal' desires, but, on the other hand, her body does not react the way her partners would like. Sexual dysfunction of one kind or another is often an effect of sexual abuse (Fleming et al. 1999:151). As she attempts to process the trauma, she has nightmares and sleepless nights, affecting her daily physical functioning while serving her intellectual pursuits. She does not get enough sleep, but she has plenty of time to study at night. In her spirit story, it is evident that her physical aversion to touch, or tactile defensiveness, makes it difficult for her to worship in a full church, as she feels nervous when she is surrounded by people. Avoiding crowds is common behaviour among sufferers of tactile defensiveness (Heller 2002:4).

In an attempt to bring her body story back into conversation with her mind and spirit stories, she has explored Tantric mindfulness practices. These are essentially spiritual practices aimed at raising one's levels of awareness, also on a sensory level, because Tantra is based on the principle that 'nothing exists that is not divine' (Wallis 2012:468). According to that principle, even the most ordinary things, such as being aware of the temperature in the room, can connect a person to the divine. Her own attempt has failed, however, and she has decided to leave matters as they are.

She tells a story of determination and will power, which has translated into a very successful academic career, in one story of the mind, as well as significant weight loss, in another account of her body.

Writing poetry is an intellectual exercise that she is fond of, and this has also served a deeply spiritual and emotional purpose. Her poetry is a creative outlet, and also serves as a vehicle for exploring issues of faith and for entering into conversation with God (Bolton 1999:118-119). Similarly, her favourite choice of exercise is to take long walks in a nearby nature reserve, which addresses a physical need of her body, while allowing her time to contemplate nature. It is in nature that she often finds confirmation of her faith and inspiration for her poetry. In her poems, she employs a large amount of natural imagery to describe God and to relate to the Divine.

Hannetjie has made a conscious effort to forgive her mother and the abuser, but she has not yet succeeded in forgiving herself. On an intellectual level, she understands the need to forgive all three persons and has found liberation in forgiving the others. Here we should note Tanyi's (2002:506) reference to forgiveness as an aspect of spirituality and healing. However, Hannetjie may understand the reasons why she should forgive herself, but she is unable to, feeling betrayed by her body.

Through her academic pursuits, she has come to understand that she need not be a slave to the traditions of the Dutch Reformed Church, as far as some of those traditions have made her feel marginalised and oppressed. As such, she rejoices in knowing that she can reinterpret the Bible for herself and seek God in other traditions that make sense to her, such as the principles of Buddhism. However, she is deeply concerned by the manner in which she was raised within this tradition and how her mother's deeply held beliefs affected her own troubled relationship with God (De Roos, Iedema \& Miedema 2004; Swart 2013:31). Lizette, the Dutch Reformed minister, mentioned in her transdisciplinary contribution that it might be valuable for Hannetjie to come to a better understanding of the other side of sin: forgiveness and grace (Watson, Morris \& Hood 1988).

Lastly, in seeking recovery, she has searched for ways to bring the different body, mind and spirit stories into conversation, and to reconnect with her physicality and emotions. She has done this by studying matters of faith and sexuality academically, and by engaging with God in poetry and elsewhere. An aspect of our relationship with God is revealed when we seek and experience healing or recovery, as Jesus is the bringer of healing and liberation, through forgiveness (Busch 2010:92).

Thus, it is evident that Hannetjie's spirit stories did not develop in a vacuum and we cannot begin to understand her spirituality as if it exists independently from the rest of her personhood (Thomas 2000).

\section{Conclusion}

In this article, I illustrated the practical usefulness of transdisciplinary work for practical theology by illustrating how input from an occupational therapist informed my understanding and interpretation of the story of Hannetjie, who had been sexually abused as a child, as part of a larger transdisciplinary conversation. The knowledge gained from the occupational therapist added a whole new layer to my reading of Hannetjie's story by clarifying how one's sensory experiences can play a role in one's 
perception of oneself and one's life. Initially, I offered a brief explanation of why transdisciplinary work can be helpful for theology, by referring to Müller (2009, 2013) and Van Huyssteen (2006). A brief, redacted, retelling of Hannetjie's story was given, so that readers could know the background to the story that the transdisciplinary team members were offered. Next, the process that was followed and the questions that the co-researchers had to respond to were discussed. Following that, I focused more specifically on Debra Smuts's answers, and the knowledge gained from her contribution, as an example of how a co-researcher from a divergent discipline can inform a theological study. Lastly, the interrelationship between Hannetjie's body stories, mind stories, and spirit stories was discussed to show how the learning from occupational therapy coloured my thinking about her stories and the relationships between them.

As a result, I conclude that transdisciplinary work has great value for practical theology, especially in the pastor's daily work with people who are struggling with difficult stories. It is my hope that transdisciplinary work should not only be of interest as an element of research, but that it should also form part of all pastoral caregivers' own development in their regular work with people.

\section{Acknowledgements}

A word of thanks to Debra Smuts (Occupational Therapist) for her contribution to this research.

\section{Competing interests}

The authors declare that they have no financial or personal relationships that may have inappropriately influenced them in writing this article.

\section{Authors' contributions}

This article is a reworked version of a section of H.H.'s (University of Pretoria) PhD dissertation, with J.C.M. (University of Pretoria) as supervisor.

\section{References}

Ayers, A.J., 2005, Sensory integration and the child: Understanding hidden sensory challenges, Western Psychological Services, Torrance, CA.

Bass, E. \& Davis, L., 2002, The courage to heal: A guide for women survivors of child sexual abuse, Vermilion, London.

Bolton, G., 1999, "'Every poem breaks a silence that had to be overcome": The therapeutic power of poetry writing', Feminist Review 62(1), 118-133. http:// dx.doi.org/10.1080/014177899339225

Bundy, A.C. \& Murray, E.A., 2002, 'Sensory integration: A Jean Ayres' theory revisited' in A.C. Bundy, S.J. Lane \& E.A. Murray (eds.), Sensory integration: Theory and practice, pp. 3-33, 2nd edn., FA Davis Company, Philadelphia, PA.

Busch, E., 2010, Drawn to freedom: Christian Faith today in conversation with the Heidelberg Catechism, WB Eerdmans Publishing Company, Grand Rapids, MI.

Campbell, A.V., 1986, Rediscovering pastoral care, Longman \& Todd, Darton, GA.

De Roos, S.A., ledema, J. \& Miedema, S., 2004, 'Influence of maternal denomination God concepts, and child-rearing practices on young children's God concepts', Journal for the Scientific Study of Religion 43(4), 519-535. http://dx.doi. org/10.1111/j.1468-5906.2004.00253.x

Epston, D., 1999, Co-research: The making of an alternative knowledge, Dulwich Centre Publications, Adelaide.
Finkelhor, D. (ed.), 1986, A sourcebook on childhood sexual abuse, SAGE Publications, Beverly Hills, CA

Finkelhor, D., 1990, 'Early and long-term effects of child sexual abuse: An update', Professional Psychology: Research and Practice 21(5), 325-330. http://dx.doi. org/10.1037/0735-7028.21.5.325

Fleming, J., Mullen, P.E., Sibthorpe, B. \& Bammer, G., 1999, 'The long-term impact of childhood sexual abuse in Australian women', Child Abuse \& Neglect 23(2) 145-159. PMID: 10075184, http://dx.doi.org/10.1016/S0145-2134(98)00118-5

Foucault, M., 1982, 'The subject and power', Critical Inquiry 8(4), 777-795.

Fuqua, J., Stokols, D., Gress, J., Phillips, K. \& Harvey, R., 2004, 'Transdisciplinary collaboration as a basis for enhancing the science and prevention of substance use and "abuse"', Substance Use \& Misuse 39(10/12), 1457-1514. PMID: 15587944.

Hagood, M., 2000, The use of art in counselling child and adult survivors of sexual abuse, Jessica Kingsley Publishers, London.

Heitritter, L. \& Vought, J., 2006, Helping victims of sexual abuse: A sensitive Biblical guide for counselors, victims and families, Bethany House, Minneapolis, MN.

Heller, S., 2002, Too loud, too bright, too fast, too tight: What to do if you are sensory defensive in an overstimulating world, Harper, New York, NY.

Jeeves, M., 2014, 'Brains, minds, souls, and people: A scientific perspective on complex human personhood,' in M. Welker (ed.), The depth of the human person: A multidisciplinary approach, pp. 93-108, WB Eerdmans Publications, Grand Rapids, MI.

Kinnealey, M., Oliver, B. \& Wilbarger, P.A., 1995, 'Phenomenological study of sensory defensiveness in adults', The American Journal of Occupational Therapy 49(5), 444-451. http://dx.doi.org/10.5014/ajot.49.5.444, PMID: 7598160.

Lane, S.J., 2002, 'Sensory modulation,' in A.C. Bundy, S.J. Lane \& E.A. Murray (eds.), Sensory integration: Theory and practice, pp. 101-122, 2nd edn., FA Davis Company, Philadelphia, PA.

Lombard, A., 2007, Sensory Intelligence: why it matters more than IQ and EQ, Metz Press, Welgemoed.

Lyon, E., 2010, 'The spiritual implications of interpersonal abuse: Speaking of the soul', Pastoral Psychology 59, 233-247. http://dx.doi.org/10.1007/s11089-009-0238-2

Madigan, S., 2011, Narrative Therapy, Kindle Edition, American Psychological Association, Washington, DC.

Maiese, M., 2011, Embodiment, emotion, and cognition, Palgrave Macmillan, Hampshire.

McClure, B. \& Miller-McLemore, B.J., 2012, 'Pastoral care', in B.J. Miller-McLemore (ed.), The Wiley-Blackwell companion to practical theology, pp. 269-278, WileyBlackwell, Oxford.

Merrill, L.L., Thomsen, C.J., Sinclair, B.B., Gold, S.R. \& Milner, J.S., 2001, 'Predicting the impact of child sexual abuse on women: The role of abuse severity, parental support, and coping strategies', Journal of Consulting and Clinical Psychology 69(6), 992-1006. http://dx.doi.org/10.1037//0022-006X.69.6.992, PMID: 11777126

Monk, G., Winslade, J., Crocket, K. \& Epston, D., 1997, Narrative therapy in practice: The archeology of hope, Jossey-Bass Publishers, San Francisco, CA. (Kindle edn.).

Müller, J.C., 2009, 'Transversal rationality as a practical way of doing interdisciplinary work, with HIV and Aids as a case study', Practical Theology in South Africa 24(2), 199-228.

Müller, J.C., 2011, 'Post-foundational practical theology for a time of transition', HTS Teologiese Studies/Theological Studies 67(1), 1-5. http://dx.doi.org/10.4102/hts. v67i1.837

Müller, J.C., 2013, 'Practical theology as part of the landscape of social sciences and humanities: A transversal perspective', HTS Teologiese Studies/Theological Studies 69(2), 1-5. http://dx.doi.org/10.4102/hts.v69i2.1299

Palmer, S.E., Brown, R.A., Rae-Grant, N.I. \& Loughlin, M.J., 1999, 'Responding to children's disclosure of familial abuse: What survivors tell us', Child Welfare LXXVIII(2), 259-282. PMID: 10418117.

Pfeiffer, B. \& Kinnealey, M., 2003, 'Treatment of sensory defensiveness in adults', Occupational Therapy International 10(3), 175-184. http://dx.doi.org/10.1002/ oti.184

Scruton, R., 2011, 'Neurononsense and the soul,' in J.W. van Huyssteen \& E.P. Wiebe (eds.), In search of self: Interdisciplinary perspectives on personhood, pp. 338-356, WB Eerdmans Publications, Grand Rapids, MI.

Steine, I.M., Krystal, J.H., Nordhus, I.H., Bjortvan, B., Harvey, A.G., Eid, J. et al., 2011, 'Insomnia, nightmare frequency, and nightmare distress in victims of sexual abuse: The role of perceived social support and abuse characteristics', Journal of Interpersonal Violence 27(9), 1827-1843. http://dx.doi. org/10.1177/0886260511430385, PMID: 22204947.

Swart, C., 2013, Re-authoring the world: The narrative lens and practices for organisations, communities and individuals, Knowres Publishing, Randburg.

Tanyi, R.A., 2002, 'Towards clarification of the meaning of spirituality', Journal of Advanced Nursing 39(5), 500-509. PMID: 12175360. http://dx.doi.org/10.1046/ j.1365-2648.2002.02315.x

Thomas, O., 2000, 'Some problems in contemporary Christian spirituality', Anglican Theological Review 82(2), 267-281.

Turner, L., 2001, 'The paradox of the self and its implications for concepts of personhood: Contrasting contemporary theological and psychological approaches to an old problem', The Journal of Faith and Science Exchange 5, 197-209.

Van Huyssteen, J.W., 2006, Alone in the world? Human uniqueness in science and technology: The Gifford Lectures, WB Eerdmans Publications, Grand Rapids, MI. (Kindle edn.). 
Van Jaarsveld, A., 2012, 'Sensory modulation disorder: Clinical reasoning in sensory integration', The South African Institute for Sensory Integration Newsletter 22(3), 13-19.

Wallis, C., 2012, Tantra illuminated: The philosophy, history, and practice of a timeless tradition, Mattamayūra Press, Petaluma, CA.
Watson, P.J., Morris, R.J. \& Hood, R.W., 1988, 'Sin and self-functioning: I. Grace, guilt, and self-consciousness.', Journal of Psychology and Theology 16(3), 254-269.

Wilson, K.R., Hansen, D.J. \& Li, M., 2011, 'The traumatic stress response in child maltreatment and resultant neuropsychological effects', Aggression and Violent Behavior 16(2), 87-97. http://dx.doi.org/10.1016/j.avb.2010.12.007 